\title{
A magyar katonai ejtőernyőzés története 1948-tól napjainkig
}

A második világháború befejezését követően megkezdődött a honvédség újraszervezése. A Magyar Honvédség 1945-től 1948-ig tartó időszakában nem rendelkezett ejtőernyős alakulattal. 1948-ban a katonai felső vezetés felállította az úgynevezett „PILIS II.” hadrendet, amelybe egy század erejű légideszant erő tartozott. 1948 októberére megalakult az Első Honvéd Önálló Ejtőernyős Század Szolnokon. 1949-ben a „Klapka” hadrend alapján zászlóalj szintűre fejlesztették az alakulatot. A zászlóalj egy ejtőernyős és egy nehézfegyveres századból állt, egy műszaki és egy szállítószakasz támogatásával. Ezt követően, két éven keresztül a zászlóalj sorozatos költözésekre kényszerült, előbb Tapolcára, onnan Kaposvárra, majd Sóstóra települtek. Ekkor állapították meg az alakulat legnagyobb hiányosságait. Az alakulat ugyanis - bár a személyi állománya $82 \%$-os feltöltöttségű volt - nem rendelkezett nehézfegyverzettel. Így rendeltetését, amely a légi szállítással az ellenség mélységében, mögöttes területein folytatandó harc volt, nem tudta kellő eredményességgel elvégezni. A felső vezetés választás elé került: vagy elkezdik az ejtőernyős alakulat nagymértékü fejlesztését, vagy újragondolják a zászlóalj alkalmazási elveit.

\section{1. ábra. Korabeli felvétel az újkígyósi gyakorlatró}

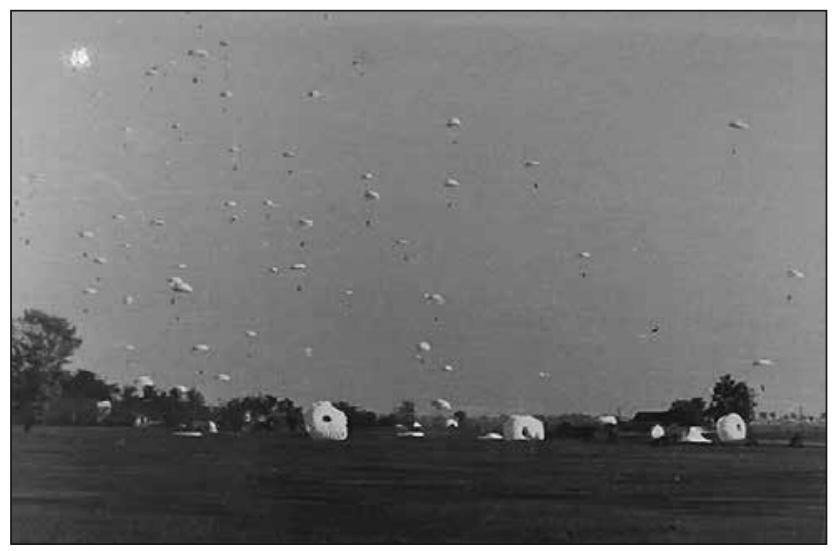

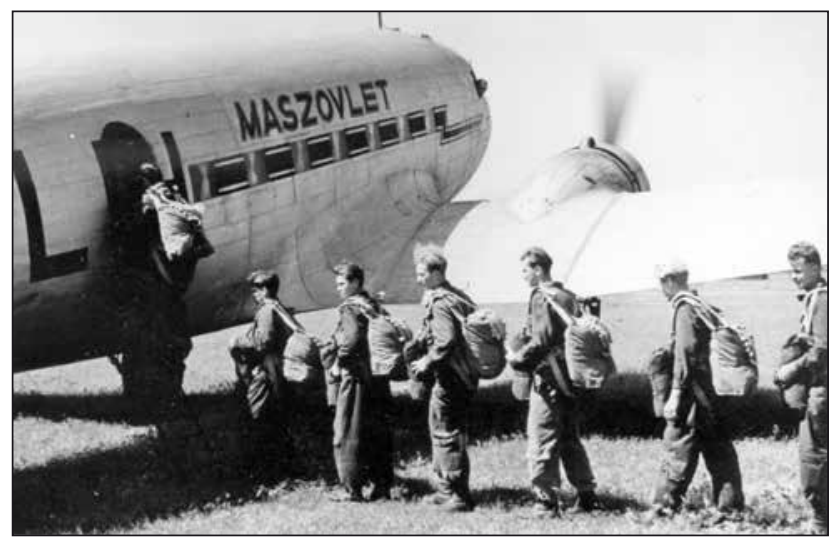

2. ábra. A Liszunov Li-2-es repülögép utasszállító változata. Az 1950-es évek elején a Maszovlet (Magyar-Szovjet Polgári Légiforgalmi Részvénytársaság) repülőgépeit is igénybe vették az ejtőernyősök ugratásához. A Li-2-esek folyamatos kihasználtságának érdekében sok esetben az utasülések kiszerelésére sem volt idő (Fotó: Zainkó Géza gyűjteményéből)

1952 fontos év volt az ejtőernyősök életében. A vezérkar az év őszére az alföldi Újkígyós-Szabadkígyós térségben egy, az egész Magyar Néphadsereget megmozgató többnapos gyakorlatot tervezett. A hadgyakorlat egyik föszereplője az ejtőernyős zászlóalj volt, amelynek feladata, hogy kötelékugrást végrehajtva, a deszantos katonák a harcmezőn feltartóztatják a támadó ellenséget, így felmentik a védőket.

1952. október 18-án került sor a Magyar Néphadsereg történetének legnagyobb ejtőernyős gyakorlatára, amely során 22 repülőgép szállította az ejtőernyősöket. A gyakorlat közben fény derült az alakulat hiányosságaira: a zászlóalj nehézfegyverzet hiányában képtelen volt kellő hatásfokkal támogatni a védelemre szoruló felet, és a támadó fél páncélosainak hatékony elhárítására sem lett volna képes. Ezek után komolyabb szemléletváltásra került sor az alakulattal kapcsolatban. A szervezet feladatát a rendelkezésre álló felszereléshez igazították, ezzel gyökeresen megválto-
ÖSSZEFOGLALÁS: A cikk a magyar katonai ejtőernyőzés történetét foglalja össze 1948-tól napjainkig. A néphadseregben az ejtőernyősök fő feladata a felderítés volt, az ugrásokat a sokáig korszerünek számító Mi-8-as helikopterekből és An-26-os szállítórepülögépekből hajtották végre. A kilencvenes évek haderő-átalakitása az ejtőernyős alakulatok életébe is jelentős változásokat hozott. Napjainkban feladataikat a MH 2. vitéz Bertalan Árpád Különleges Rendeltetésủ Dandár kötelékében hajtják végre.

KULCSSZAVAK: Magyar Honvédség, Önálló Ejtőernyős Század, Szolnok, felderítố-zászlóalj, gyorsreagálású, Különleges Rendeltetésú Dandár
ABSTRACT: This article summarizes the history of Hungarian military parachuting from 1948 to the present. In the Hungarian People's Army, the main task of the paratroopers was reconnaissance, jumps were made from Mi-8 helicopters and An-26 transport aircraft, which were considered modern for a long time. The armed force transformation in the 1990s brought about significant changes in the life of paratrooper units. Nowadays, they execute their tasks in the frame of the HDF 2nd Árpád Bertalan Special Purpose Brigade.

KEY WORDS: Hungarian Defence Forces, Independent Parachute Company, Szolnok, reconnaissance battalion, rapid reaction, Special Purpose Brigade

\footnotetext{
Hadnagy, MH 5. Bocskai István Lövészdandár. ORCID: 0000-0003-2072-1975
} 
zott a zászlóalj arculata. Az alegység mélységi felderítő és diverziós zászlóalj lett. A kiképzés mélyen az ellenség vonalai mögötti, kiscsoportos műveletek felé orientálódott. Ez azonban már az alakulat hanyatló időszaka volt. 1954-ben az általános haderőcsökkentés következtében megszüntették az ejtőernyős zászlóaljat, és 1959-ig a Magyar Néphadsereg nem rendelkezett ejtőernyős alakulattal.

\section{AZ ÚJRAKEZDÉS IDŐSZAKA}

1959-ben az egyre inkább kiéleződő hidegháborús hangulat felhívta a katonai felső vezetés figyelmét arra, hogy a Magyar Néphadseregnek szüksége van egy olyan alegység megalakítására, amely növeli a felderítés hatékonyságát, mélységében nyugtalanítja az ellenség erőit, képes adatokkal szolgálni az esetleges tömegpusztító fegyverekről és szükség esetén késleltetni azok alkalmazását, vagy semlegesíteni azokat. Ezzel az alkalmazási elvvel alakult meg 1959. október 14-én, vezérkar közvetlen irányítású alakulataként a 34. önálló mélységi felderítőszázad. Az első idekerült tisztek, köztük Tóth Gábor és Kozma József őrnagyok dolgozták ki az alegység alkalmazási elveit. Ennek a koncepciónak az eredménye a 6-8 fő alkalmazása egy csoportban, 300-500 kilométeres mélységben. A felderítőcsoportot 4-5 napig alkalmazza a felső vezetés, majd bevonják őket. A kiképzés központi eleme a felderítés, és az ejtőernyővel való kijutás gyakorlása.

1962 őszén a felderítőszázadot zászlóaljjá szervezték át, és 4 mélységi felderítő-szakasszal Budapestről Szolnokra költözött. A zászlóalj új elnevezése 34. önálló különleges felderítő zászlóalj lett. Az évek során lassacskán kialakult a zászlóalj szervezete, amely a '90-es évekig változatlan maradt. A zászlóalj a törzsön kívül három századból és egy híradókiképzőszázadból állt. Egy század létszáma 80 fő volt, amely három darab, négyrajos szakaszból állt. Egy raj alkotott egy mélységi felderítő-csoportot, ami a parancsnokból, a helyetteséből, egy távírászból és négy felderítőből állt.

A 34. felderítő-zászlóalj megalakításával párhuzamosan további felderítő-zászlóaljak alakultak meg Kiskunfélegyházán, Szombathelyen, Újdörögdön, Kaposváron és Tatán. Ezek a zászlóaljak csapat- és mélységi felderítő-századokból álltak.

A '70-es évek végén a szolnoki parancsnokok újragondolták a mélységi felderítők alkalmazási elveit. Az első változás az alkalmazás mélysége volt, ugyanis a néphadsereg nagyobb hatótávolságú légi szállítóeszközöket ka-

\section{3. ábra. Szombathelyi ejtőernyős katonák az 1980-as évek} végén

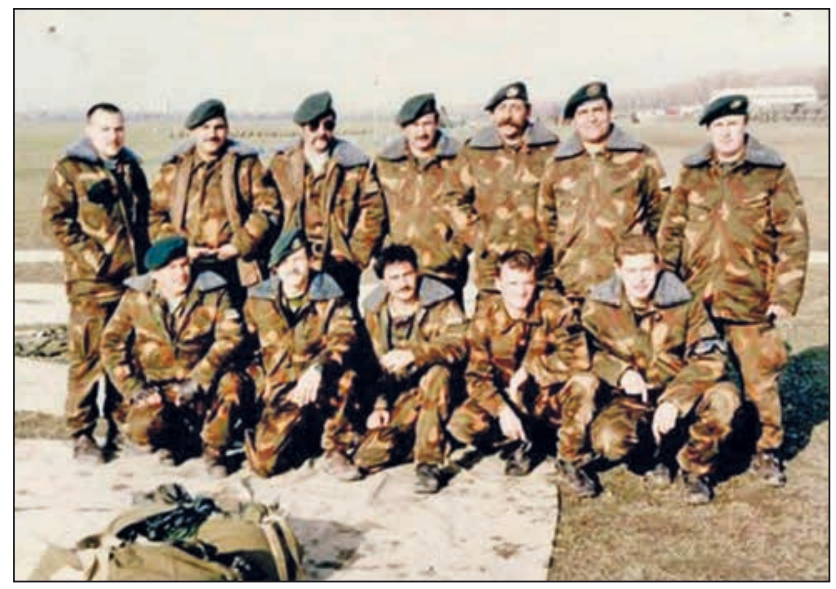

pott. Ennek köszönhetően a mélységi felderítő-csoportokat nagyobb mélységben, akár 1000 km-el az ellenség vonalai mögött is lehetett alkalmazni. Az alkalmazás ideje 10-12 napra nőtt. Ezt követően a '90-es évekig nagyobb változást nem vehetünk észre a zászlóaljak életében, struktúrájukban.

A '90-es évek második felétől, az állam romló anyagi helyzete miatt a hadsereg létszámát nagy mértékben csökkentette a hadvezetés. Ez alól a felderítő-alakulatok sem jelentettek kivételt. Ebben az időszakban az ország összes felderítő-zászlóalját felszámolták, az egri 24. Bornemissza Gergely felderítő zászlóaljat és a szolnoki 34. Bercsényi László önálló mélységi felderítő zászlóaljat kivéve.

2007-ben az egri zászlóaljat is megszűntették, jogutódja, az MH 5. Bocskai István Lövészdandár alárendeltségében a $\mathrm{MH}$ 5/24. Bornemissza Gergely Felderítő Zászlóalj Debrecenben, ami 2017. november 1-től kivált a dandár szervezetéből és önálló felderítő-ezredként működik tovább.

$A z$ ezred rendelkezik mélységi felderítő-századdal, így napjainkban ez az egyetlen alegység, amely a mélységi felderítő kultúrát képviseli. Az ezreden belül egy EHV (elektronikai hadviselés) század, két felderítő-század és egy támogató szakasz működik. Emellett az ezred speciális képessége például a HUMINT (Human Intelligence ügynöki hírszerzés) és az UAV (unmanned aerial vericle pilóta nélküli légi jármú). Az ezred állományában körülbelül 30 fő rendelkezik ejtőernyős-képesítéssel. Az ejtőernyős kiképzést az ernyő fajtáját tekintve két csoportba osztják: légcellás ejtőernyős ugrásra és körkupolás ugrásra. Légcellás ejtőernyővel legalább 40-50 ugrást kell végrehajtania a katonának annak érdekében, hogy megőrizze a minősítést, míg körkupolás ejtőernyőnél ez a szám 12.

A szolnoki 34. felderítő zászlóalj is átalakult a '90-es évek második felében. A három 80 fős század megmaradt, de egy század ettől kezdve kettő szakaszból állt, a szakaszt pedig nem négy, hanem három raj alkotta.

1993-ban a felderítő-zászlóaljból kivált állományból létrehozták az $\mathrm{MH}$ 88. Légimozgékonyságú Zászlóaljat, a Magyar Honvédség első légimozgékony szervezetét. A katonai felső vezetés a zászlóalj megalakításával egy olyan alakulatot kívánt szervezni, amely szükség esetén bárhol, bármikor, bármilyen körülmények között alkalmazható. Így feladatai nagyon széles skálán mozogtak. Ebből következően a zászlóalj összfegyvernemi alegység szakalegységekkel, légi szállításra alkalmas felszereléssel, haditechnikai eszközökkel.

A haderő-átalakítás keretein belül a zászlóaljat 1996. március 1-től átszervezték, és gyorsreagálású zászlóaljként müködött tovább. A zászlóalj létszáma 488 főről 650 re emelkedett, és 2000. október 1-én a zászlóalj ismét átalakult, a szervezet megnevezése MH 1. Könnyü-Vegyes Ezred lett. Az ezred létszáma 1028 fő volt, amely 2004-ig tovább bővült. $A z$ alakulat jelentős erővel rendelkezett (5 manőverszázad), azonban a légi szállítással kapcsolatban problémákkal küszködött, ugyanis a légierő An-26 típusú gépei 5500 kg-os szállítókapacitása nem teszi lehetővé 


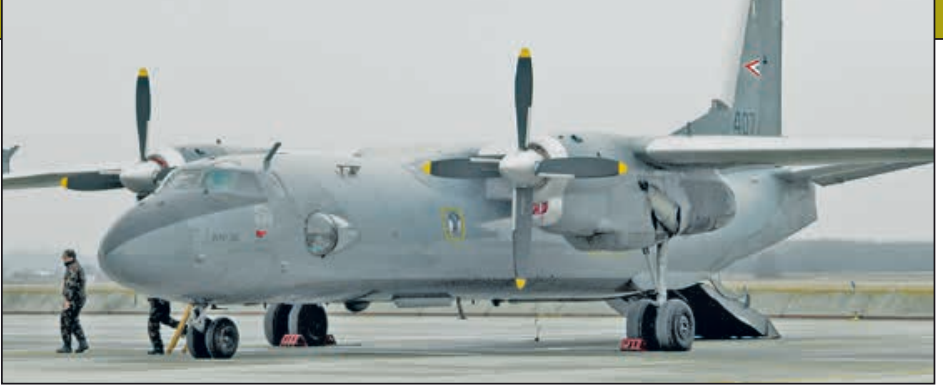

5. ábra. An-26 típusú szállító repülőgép (Fotó: Baranyai László)

páncélozott harcjárművek légi szállítását. Így a légimozgékony egységek és az ejtőernyősök nem rendelkeztek gépesített megerősítéssel.

Az ezred a katonáit speciális feladatokra (helységharc, ejtőernyős képzés, hegyi kiképzés, légi szállítás) is kiképezte. Az újabb haderő-átalakítás következtében a szervezet megszúnt, és MH 25/88. Könnyű Vegyes Zászlóalj néven betagozódott a MH 25. Klapka György lövészdandárba. 2005-től a zászlóalj beköltözött a szolnoki Ittebei Kiss József helikopter bázisra, az MH 86. Helikopter Ezred laktanyájába. A zászlóalj az átalakítások ellenére minden téren megőrizte jogelődje többfunkciós képességeit. A gyakorlatokat, kiképzési feladatait a zászlóalj az MH 86. Szolnok Helikopter Bázissal együttműködésben hajtotta végre.

Az alegység alapvetően könnyű gyalogos összfegyvernemi katonai szervezet volt, de fö feladata a különleges műveleti zászlóalj tevékenységének támogatása. A zászlóalj alap harcászati műveleti alegységei a gyorsreagálású századok, amelyeket a feladat jellegétől függően a szükséges megerősítő, támogató és kiszolgáló elemekkel csoportosítva alkalmaz. Haditechnikai felszerelése, fegyverzete könnyű, málházott eszközökből állt. A zászlóalj több alkalmazási módnál használta az ejtőernyőzést. Az egyik módszer a zászlóalj harctámogató század felderítőszakaszának ejtőernyős kijuttatása. A felderítőszakaszt két felderítő- és egy mesterlövészraj alkotja. A szakaszban minden katona ejtőernyős képzettséggel rendelkezik. Feladatuk információszerzés saját alegységeik számára. A felderítő csoportok 4 fővel működnek. Az ejtőernyős dobás másik alkalmazási módja a zászlóaljnál a tömeges dobás. Az első gyorsreagálású század rendelkezett ejtőernyős képességekkel. Az alegység komoly problémája, a már korábban említett légi gépesítés hiánya. A zászlóalj rendelkezett helikopterdeszant képességgel is.

Az MH 34. Bercsényi László Felderítő Zászlóalj egészen 2005. szeptember 1-ig, a korábban említett szervezet szerint müködött. Az aszimmetrikus kihívásokból adódó feladatok, mint például a nemzetközi terrorizmus elleni harc, újfajta képességek megteremtését igényelte. A katonai felső vezetés ennek kapcsán döntött úgy, hogy megalakít - a Magyar Honvédség történetében először - egy külön-

\section{6. ábra. A 25/88. könnyű vegyes zászlóalj katonái vízi} kiképzés közben

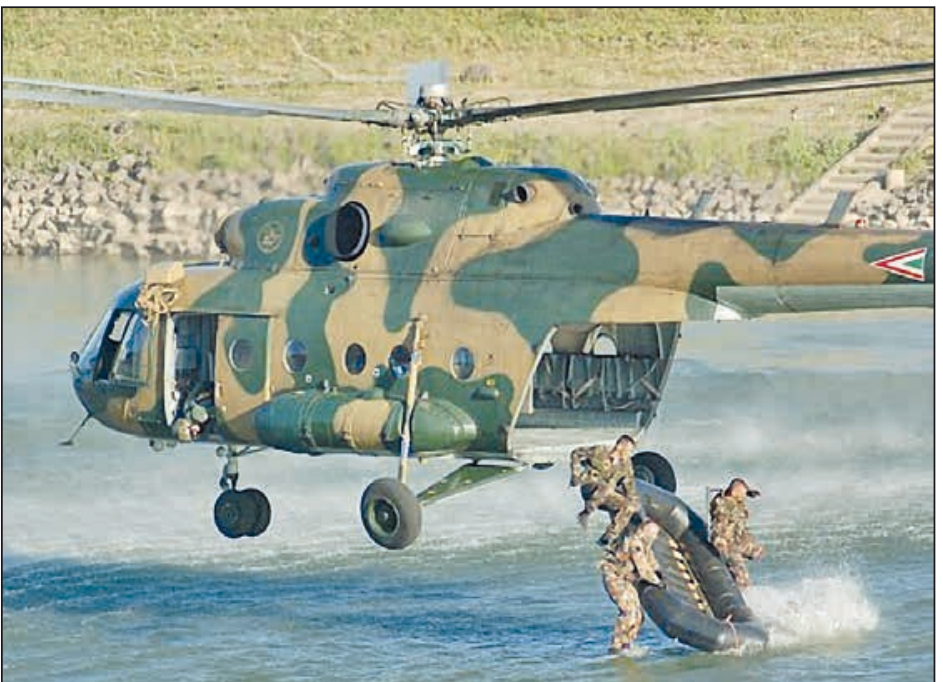

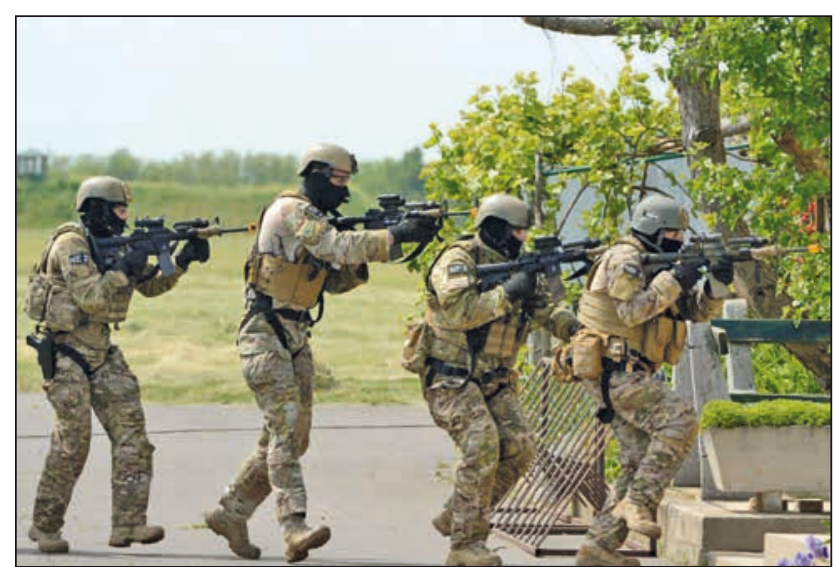

7. ábra. A különleges műveleti zászlóalj katonái kiképzést hajtanak végre

leges feladatok végrehajtására kijelölt egységet.

Ezért 2005-ben a felderítő-zászlóaljat átalakították különleges műveleti zászlóaljjá. A zászlóalj fő feladata a különleges műveletekben való részvétel. A különleges erők feladatai sokrétűek, amelyeket a szakirodalom négy nagy kategóriába sorol: különleges felderítésre, közvetlen akciókra, katonai segítségnyújtásra és a terrorizmus elleni harcra.

A két szolnoki zászlóalj pályája 2016. január 1-jén fonódott össze, amikor megalakult az $\mathrm{MH}$ 2. vitéz Bertalan Árpád Különleges Rendeltetésü Ezred, majd

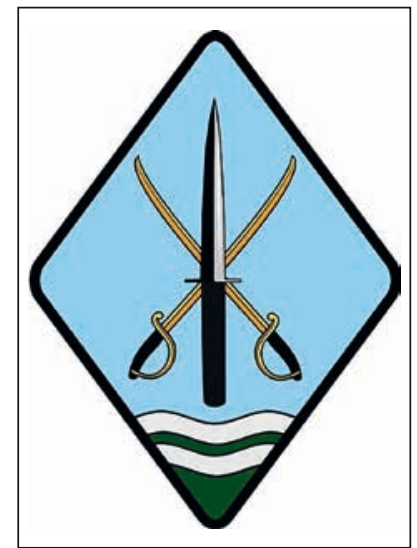

8. ábra. Az MH 2. vitéz Bertalan Árpád Különleges Rendeltetésű Dandár karjelzése ezt követően 2017. szeptember 1-én megalakult a MH 2. vitéz Bertalan Árpád Különleges Rendeltetésű Dandár. A dandár sajátos szervezeti struktúrával rendelkezik, ugyanis nem zászlóaljakból, vagy századokból, hanem $4 \mathrm{db}$ osztagból épül fel. Mindegyik osztag $5 \mathrm{db}$ csoportból áll. Azonban ez a struktúra még nem teljesen kiforrott, jelenleg erről kevés információval rendelkezünk.

\section{ForRÁsOK}

A magyar katonai ejtőernyőzés története, főiskolai tankönyv, Budapest, ZMNE, 2003.;

Turcsányi Károly - Hegedűs Ernő: A magyar légideszantcsapatok alkalmazásának, haditechnikai eszközeinek és szervezetének fejlődése (1933-1945) I-II. rész. Katonai Logisztika 2006. évi 3-4. sz.;

Dr. Ruszin Romulusz - Dr. Boda József: Levegőből harcba - A magyar katonai ejtőernyőzés története és változó feladatrendszere. Zrínyi Kiadó, Budapest, 2010.;

Szombathelyi ejtőernyős katonák. http://www.repulestudomany.hu/;

Új képesség birtokában. Honvédelem.hu, 2014. szept. 28. https://honvedelem.hu/cikk/46677_uj_kepesseg_ birtokaban [2018.10.01.];

https://honvedelem.hu/szervezet/mh_2_kulonleges_ rendeltetesu ezred. 